\title{
Biochemicals in Cotton Hybrids and Varieties and their Correlation with Sucking Insect Pests
}

\author{
V. U. Sonalkar* \\ Department of Agricultural Entomology, Dr. Panjabrao Deshmukh Krishi Vidyapeeth, \\ Akola, Maharashtra-444104, India \\ *Corresponding author
}

Keywords

Cotton, Hybrids,

Varieties, Aphid,

Leafhopper,

Whitefly, Thrips,

crude protein, Total

phenols, Total

soluble sugar

Article Info

Accepted:

15 December 2019

Available Online:

20 January 2020
A B S T R A C T

The two year experiments were conducted under field and in the laboratory with fifteen cotton cultivars as treatments replicated thrice. Observation on major sucking pest viz., aphid, leafhopper, whitefly and thrips were recorded on five plants and biochemical constituent viz., crude protein, total phenols and total soluble sugar were estimated from the leaves of cotton cultivars collected at 45 and 60 days after emergence. The biochemical were estimated by standard methods and correlated with sucking pests. Results revealed that significantly maximum crude protein noted in cultivar $\mathrm{RCH}-2 \mathrm{Bt}$ followed in $\mathrm{BNBt}, \mathrm{RCH}-2$, LRA-5166, Bunny and less crude protein in DHY-286 followed in PKVHY-2 and PKV Rajat, AKA-8 and AKA-7. Mean total sugar estimated in various cotton cultivars varied significantly with highest $(9.048 \mathrm{mg} / \mathrm{g})$ in cultivar $\mathrm{RCH}-2 \mathrm{Bt}$ and least was estimated in cultivar PKVHY-2 $(7.154 \mathrm{mg} / \mathrm{g})$ followed in PKV Rajat $(7.226 \mathrm{mg} / \mathrm{g})$. Mean total phenol in cotton leaves was on higher side in cultivar PKVHY-2 which being followed in leaves of DHY-286 and PKV Rajat. BNBt resulted least total phenol and was being followed in $\mathrm{RCH}-2 \mathrm{Bt}, \mathrm{RCH}-2$, AKA-7 and AKA-8. There was weak non-significant correlation between aphid nymphs and thrips with biochemical viz., crude protein, total sugar and total phenol in leaves. Crude protein and total sugar had significant positive impact on leafhoppers and total phenol had negative significant impact on leafhopper. Whitefly had significant positive association with total phenol; whereas, other biochemical were not played much role in imparting resistance or susceptibility.

\section{Introduction}

Of the various reasons for low productivity of cotton, damage due to various insect pests is one of the important major constraints in cotton production and often causes heavy yield losses. Among all insect pests, cotton crop suffers heavy attack of sucking insect pests like aphids Aphis gossypii Glover, leafhoppers Amrasca biguttula biguttula 
(Ishida), thrips Thrips tabaci (Lind.), whitefly Bemisia tabaci (Genn.). In the South-East Asian countries, A. biguttula biguttula is one of the major pests of cotton. Cotton whitefly damages the crop by sucking cell sap resulting in fifty per cent reduction in boll production (Ahmad et al., 2002) and also acts as vector of leaf curl virus disease (Nelson et al., 1998). The indiscriminate use of chemical pesticides for the control of major pests on cotton resulted in development of resistance to pesticides in targeted and non targeted pests, disturbance in natural balance of pests and their natural enemies, resurgence of minor pests, pollution in crop ecosystem, hazards to health and economy (Pawar and Kadam 1995) and development resistance in sucking pests (Ahmad et al., 2002). Also, farmers are not getting expected control of sucking pests by using chemical insecticides; moreover, many times there is outbreak of leafhoppers and whitefly on cotton.

To produce sustainable yield, eco-friendly pest control is needed in an integrated manner. Even though efficient chemicals are available and with drawback of chemical insecticide use, growing resistant cotton cultivars offers the cheapest and the most harmless approach in integrated pest management programme to manage sucking pest infestation. The resistant cultivar can be utilized by the breeder in their breeding programme for producing resistant genotypes which provides ecological sustainability, social constancy and economic sustainability. Thus, resistant cotton cultivars plays key task in sustainable agriculture system. There is an expertise need to generate data on certain biochemical properties and their relation with sucking pest infestation.

The sucking pest population fluctuation observes from cultivar to cultivar due to morphological characters of cotton plant, on leaves in particular. Among the most recognizable character linked with resistance is biochemical factors like protein, nitrogen, phosphorous, potassium, phenol, sugar could be involved in. Insects express potential biotic stresses to their host plants. The plants challenged by insects respond through changes in composition and properties in cell wall as well as in nutrients composition (Biosynthesis of secondary metabolites) (Hopkins and Huner, 2004). The plant protein profiles modification and alteration in plants oxidative enzymes have been reported to be among a plants first response to insect herbivore (Rafie et al., 1996; Chaman et al., 2001; Ni et al., 2001).

Now a day's varieties of cotton cultivars with different traits are grown by the farmers and also they are not getting desired effective results even with the new molecules. Therefore, some popular Bt and non Bt cotton cultivars were evaluated for their reaction to key sucking pests to find out the correlation between the population of major sucking pests with biochemical factors.

Therefore, present study is planned to study the various biochemical (phytochemical) that are present in plants, responsible for imparting resistance/ susceptibility to sucking pest in selected cotton cultivars.

\section{Materials and Methods}

\section{Experimental Details}

The present experiments were conducted under field conditions in Randomized Block Design (RBD) and in the laboratory in Completely Randomized Design (CRD) with fifteen cotton cultivars as treatments replicated thrice. The cotton cultivars randomized and same randomization and location were maintained during both the years. 
Thirteen G. hirsutum and two G. arboreum cultivars were included in the experiment for the study. The seeds of cotton cultivars were sown in $7.0 \times 4.80 \mathrm{~m}$ plot size on 4.7.2010 and 24.6.2011, respectively during first and second successive years of the study 2010-11 and 2011-12 at cultivar wise recommended plant spacing on the research farm of Cotton Research Unit, Dr. Panjabrao Deshmukh Krishi Vidyapeeth, Akola. All other intercultural operations were done as per the university recommendations and due care was taken to maintain proper growth of the crop. The crop was grown in unprotected condition. Observation on major sucking pest viz., aphid, leafhopper, whitefly and thrips on top, middle and bottom leaf per plant were recorded on five plants 45 to 60 days after emergence. Biochemical constituent viz., crude protein, total phenols and total soluble sugar in leaves of selected cotton cultivars were estimated at 45 and 60 days after emergence.

\section{Collection and preparation of samples for analysis}

The healthy plants were selected for collecting the samples from the plots of cotton cultivars. The leaves were clipped off at 45 and 60 days after emergence, dried and crushed to powder. The dried crushed leaves of each cultivar were powdered separately in grinding mill so as to pass through 60 mesh size. The powdered material was used for estimation of total soluble sugar and total phenol estimation.

\section{Estimation of crude protein}

Total nitrogen was determined by digesting the plant sample in microprocessor based digestion system using conc. $\mathrm{H}_{2} \mathrm{SO}_{4}$ and salt mixture (Piper, 1966) and distillation with automatic distillation system. Crude protein content was calculated by multiplying nitrogen percentage by a factor 6.25 .

\section{Estimation of total sugar}

In hot acidic medium glucose is dehydrated to hydroxymethyl furfural. This forms an orange-yellow colored product with phenol and has absorption maximum at $490 \mathrm{~nm}$. The basic of this reaction is the differential production of furfural when pentoses are heated with dilute acids. When either product condenses with phenol, an orange to yellow product was formed (Dubois et al., 1956).

\section{Estimation of total phenol}

Total phenol estimation can be carried out with Folin-Ciocalteu reagent (FCR). Phenol react with an oxidizing agent phosphomolybdate in Folin-Cicalteu reagent under alkaline conditions and result in the formation of a blue colored complex, the molybdenum blue which is measured at 650 nm calorimetrically (Bray and Thorpe, 1954). From the standard curve found out the concentration of phenol in the test sample and express as $\mathrm{mg}$ phenol/100g material.

Biochemical data in various cultivars were analyzed after appropriate transformation for test of significance (Gomez and Gomez, 1984). Sucking pest mean 45 and 60 DAE data was correlated with biochemical constituents.

\section{Results and Discussion}

\section{Biochemical constituents in cotton leaves}

\section{Crude protein in cotton leaves}

\section{First year}

The crude protein content data 45 DAE varied in cultivar to cultivar between 18.48 to 22.52 per cent (Table 1). Significantly high crude protein was noted in $\mathrm{RCH}-2 \mathrm{Bt}(22.52 \%)$ followed in $\mathrm{BNBt}(22.47 \%)$. The least 
percentage of crude protein was recorded in cultivar DHY-286 (18.48\%) and this was at par to protein in remaining cultivars and in NHH-44 Bt. Significantly highest of 22.43 percent crude protein at $60 \mathrm{DAE}$ was noted in RCH-2 Bt followed in BNBt (22.38). Cultivar DHY-286 noted least i.e. 18.29 per cent crude protein in PKVHY-2, AKA-7, AKA-8 and PKV Rajat. Significantly most i.e. 22.47 per cent mean crude protein 45 and 60 DAE was in cultivar $\mathrm{RCH}-2 \mathrm{Bt}$ and this was at par with protein in BNBt (22.43\%), RCH-2 (22.04\%), LRA-5166 (21.90\%), Bunny Bt (21.80\%) and KDCH-9632 Bt (21.75\%). Whereas, least crude protein was found in DHY-286 $(18.36 \%)$ followed with $18.53,18.74,19.01$ and 19.15 per cent, respectively in PKVHY-2, AKA-7, AKA-8 and PKV Rajat.

\section{Second year}

The maximum of 23.00 per cent crude protein at 45 DAE was noted in $\mathrm{RCH}-2 \mathrm{Bt}$ (Table 1) followed in BNBt (22.72\%), LRA-5166 (22.52\%), RCH-2 (22.43\%) Bunny Bt (22.14\%), KDCH-9632 Bt (22.04\%), Bunny $(21.75 \%)$ and KDCH-9632 (21.56\%).The least per cent crude protein noted in DHY-286 (18.58\%) followed in PKV HY-2, PKV Rajat, AKA-8 and AKA-7, being statistically similar with other. At $60 \mathrm{DAE}$, maximum crude protein was in $\mathrm{RCH}-2 \mathrm{Bt}(22.91 \%)$ followed in BNBt (22.62\%), LRA-5166 (22.43\%), RCH-2 (22.33\%).

The least crude protein was noted in DHY286 (18.53\%) followed in PKVHY-2, PKV Rajat, AKA-8 and AKA-7. The higher mean crude protein was in $\mathrm{RCH}-2 \mathrm{Bt}(22.96 \%)$ followed with 22.67, 22.47, 22.38, 22.09 and 21.99 per cent respectively in BN Bt, LRA5166, RCH-2, Bunny Bt and KDCH-9632 Bt. Cultivars DHY-286 noted least (18.55\%) crude protein followed in PKVHY-2 (19.08\%), PKV Rajat (19.13\%) and AKA-8 (19.68\%).

\section{Pooled}

Pooled 45 DAE mean crude protein data showed that significantly higher crude protein was noted in cultivar RCH-2 Bt with 22.76 per cent followed by 22.60 per cent in BNBt. Significantly less i.e. $18.53 \%$ was noted in DHY-286 followed by 18.87 per cent in PKVHY-2. Sixty days after emergence highest of 22.67 per cent crude protein was noted in RCH-2 Bt followed with 22.50 per cent in BNBt these proteins were not differ statistically than crude protein in cultivar RCH-2, LRA-5166, Bunny Bt, KDCH-9632 $\mathrm{Bt}$ and KDCH-9632. The least of 18.41 per cent crude protein was found in DHY-286 followed in PKVHY-2 which had 18.75 per cent protein. Mean of 45 to 60 DAE crude protein data showed that significantly maximum crude protein 22.72, per cent was noted in cultivars $\mathrm{RCH}-2 \mathrm{Bt}$ followed by $22.55,22.21,22.19$, and 2.95 per cent in BNBt, RCH-2, LRA-5166, Bunny. Whereas, significantly less i.e. 18.47 per cent protein was in DHY-286 and this was at par with protein in PKVHY-2 and PKV Rajat, AKA-8 and AKA-7.

Venktesh et al., (2016) reported total protein in cotton leaves ranging 8.38 to $7.68 \mathrm{mg} / \mathrm{g}$, $6.27 \mathrm{mg} / \mathrm{g}$ to $5.92 \mathrm{mg} / \mathrm{g}, 5.29$ to $4.97 \mathrm{mg} / \mathrm{g}$ and 4.56 to $4.17 \mathrm{mg} / \mathrm{g}$ respectively in hybrid Tulasi 144 BG II, hybrid Jadoo BG II, hybrid NCS 9605 and variety NA 1325 (Non Bt). Ramani et al., (2017) conducted study in Navsari Agricultural University on 12 cotton varieties, they noted high protein (294.68 $\mathrm{mg} / \mathrm{g}$ ) in genotype 0821-B-4-11-7 (Full okra leaf), low $(84.53 \mathrm{mg} / \mathrm{g})$ in genotype 7 IAN1327 (Red thick leaf and red flower).

\section{Total sugar in cotton leaves}

\section{First year}

Total soluble sugar 45 DAE in cotton leaves of different cultivars varied significantly from 
7.350 to $9.063 \mathrm{mg} / \mathrm{g}$ (Table 2). The utmost total sugar was observed in $\mathrm{RCH}-2 \mathrm{Bt}$ followed in $\mathrm{RCH}-2(8.987 \mathrm{mg} / \mathrm{g})$, BNBt $(8.893 \mathrm{mg} / \mathrm{g})$, Bunny Bt $(8.847 \mathrm{mg} / \mathrm{g})$, Bunny $(8.680 \mathrm{mg} / \mathrm{g}), \quad \mathrm{NHH}-44 \mathrm{Bt}(8.550 \mathrm{mg} / \mathrm{g})$, NHH-44 (8.477 mg/g) and KDCH-9632 Bt $(8.323 \mathrm{mg} / \mathrm{g})$. The least total sugar was found in PKV HY-2 $(7.350 \mathrm{mg} / \mathrm{g})$ followed in DHY-286, AKA-7, AKA-8 and LRA-5166. The cultivar RCH-2 Bt noted highest total sugar and PKVHY-2 noted lowest total sugar in leaves 60 days after emergence. The minimum total sugar followed in PKV Rajat $(6.947 \mathrm{mg} / \mathrm{g})$, DHY-286 (7.023 mg/g), AKA$7(7.063 \mathrm{mg} / \mathrm{g})$, AKA-8 $(7.067 \mathrm{mg} / \mathrm{g})$, LRA$5166(7.547 \mathrm{mg} / \mathrm{g})$ and $\mathrm{KDCH}-9632(7.889$ $\mathrm{mg} / \mathrm{g}$ ). Mean of 45 and 60 DAE total sugar data showed that the maximum TSS was in $\mathrm{RCH}-2 \mathrm{Bt}(8.982 \mathrm{mg} / \mathrm{g})$ followed in cultivars viz., BN Bt $(8.881 \mathrm{mg} / \mathrm{g}), \mathrm{RCH}-2$ (8.866 $\mathrm{mg} / \mathrm{g})$, Bunny Bt $(8.691 \mathrm{mg} / \mathrm{g})$, Bunny $(8.557$ $\mathrm{mg} / \mathrm{g}) \mathrm{NHH}-44 \mathrm{Bt}(8.331 \mathrm{mg} / \mathrm{g})$ and NHH-44 $(8.269 \mathrm{mg} / \mathrm{g})$. The least total sugar was in cultivar PKV HY-2 $(7.128 \mathrm{mg} / \mathrm{g})$ followed in PKV Rajat, DHY-286, AKA-7, AKA-8 and LRA-5166.

\section{Second year}

The highest of $9.117 \mathrm{mg} / \mathrm{g}$ total sugar at 45 days after emergence (Table 2) was found in $\mathrm{RCH}-2 \mathrm{Bt}$, however it was at par to total sugar in cultivars BNBt, RCH-2, Bunny Bt, Bunny, NHH-44 and NHH-44 Bt with 9.014, 8.944, 8.887, 8.698, 8.414 and $8.407 \mathrm{mg} / \mathrm{g}$, respectively. PKVHY-2 had least total sugar i.e. $7.379 \mathrm{mg} / \mathrm{g}$ followed by $7.445,7.507$, $7.573,7.605,7.962$, and $8.207 \mathrm{mg} / \mathrm{g}$ observed in DHY-286 AKA-7, PKV Rajat, AKA-8, LRA-5166 and KDCH-9632 Bt, respectively and all there were at par with each other.

The highest amount of total sugar was found in RCH-2 Bt. $(9.110 \mathrm{mg} / \mathrm{g})$ at 60 DAE. Total Sugar in RCH-2, BNBt, Bunny Bt and Bunny was at per with RCH-2 Bt. NHH-44 Bt (8.175 $\mathrm{mg} / \mathrm{g}) \mathrm{NHH}-44(8.105 \mathrm{mg} / \mathrm{g}), \mathrm{KDCH}-9632$ $(8.048 \mathrm{mg} / \mathrm{g})$ and $\mathrm{KDCH}-9632(8.040 \mathrm{mg} / \mathrm{g})$ were having moderate total sugar. Cultivar PKV Rajat showed minimum total sugar i.e. $6.937 \mathrm{mg} / \mathrm{g}$ followed in PKVHY-2 $(6.980$ mg/g), AKA-7 (7.014), DHY-286 (7.092 $\mathrm{mg} / \mathrm{g})$ AKA-7 $(7.148 \mathrm{mg} / \mathrm{g})$ and LRA-5166 $(7.608 \mathrm{mg} / \mathrm{g})$ which were at par to each other.

The mean total sugar 45 and 60 DAE total sugar was ranged from 7.180 in PKVHY-2 to $9.114 \mathrm{mg} / \mathrm{g}$ in $\mathrm{RCH}-2 \mathrm{Bt}$. The total sugar in $\mathrm{RCH}-2 \mathrm{Bt}$ was statistically similar to total sugar in BNBt $(8.939 \mathrm{mg} / \mathrm{g}), \mathrm{RCH}-2$ (8.905 $\mathrm{mg} / \mathrm{g})$, Bunny Bt $(8.752 \mathrm{mg} / \mathrm{g})$ and Bunny $(8.547 \mathrm{mg} / \mathrm{g})$. The total sugar in cultivar PKV HY-2 was minimum and was at par with $7.255,7.261,7.269,7.377$ and $7.785 \mathrm{mg} / \mathrm{g}$ estimated in PKV Rajat AKA-7, DHY-286, AKA-8 and LRA -5166, respectively.

\section{Pooled}

The highest total sugar 45 days after emergence (table 2) was found in cultivar $\mathrm{RCH}-2 \mathrm{Bt}(9.090 \mathrm{mg} / \mathrm{g})$ followed in $\mathrm{BN} \mathrm{Bt}$ $(8.999 \mathrm{mg} / \mathrm{g}), \mathrm{RCH}-2(8.965 \mathrm{mg} / \mathrm{g})$, Bunny Bt $(8.867 \mathrm{mg} / \mathrm{g})$ and Bunny $(8.689 \mathrm{mg} / \mathrm{g})$. Lowest total sugar was estimated in cultivar PKVHY-2 (7.365 mg/g) followed by 7.424, $7.465,7.509$ and $7.583 \mathrm{mg} / \mathrm{g}$ in DHY-286, AKA-7, PKV Rajat and AKA-8 respectively. Cultivar KDCH-963 and KDCH-9632 Bt noted 8.204 and $8.265 \mathrm{mg} / \mathrm{g}$ total sugar and were at par to each other and with LRA-5166.

The pooled mean of total sugar estimated at 60 days after emergence was highest $(9.005$ $\mathrm{mg} / \mathrm{g}$ ) in $\mathrm{RCH}-2 \mathrm{Bt}$ and lowest $(6.942 \mathrm{mg} / \mathrm{g}$ was) in PKVHY-2. The total sugar in $\mathrm{RCH}-2$ Bt was followed with 8.821, 8.805, 8.576 and 8. $416 \mathrm{mg} / \mathrm{g}$ estimated in BNBt, $\mathrm{RCH}-2$, Bunny Bt and Bunny; the latter two being at par with NHH-44, KDCH-9632 and their counter parts Bt. The least total sugar was in PKV Rajat (6.942 $\mathrm{mg} / \mathrm{g})$ followed in 
ascending order by 6.943, 7.037, 7.038, 7.038, 7.108 and $7.578 \mathrm{mg} / \mathrm{g}$ in PKV HY-2, DHY-286, AKA-7, AKA-8 and LRA-5166, respectively.

The mean total sugar estimated in various cotton cultivars varied significantly with highest $(9.048 \mathrm{mg} / \mathrm{g})$ in cultivar RCH-2 Bt. It was followed by $8.910,8.885$ and $8.722 \mathrm{mg} / \mathrm{g}$ in BNBt, RCH-2 and Bunny Bt, respectively. The least total sugar was estimated in cultivar PKVHY-2 (7.154 $\mathrm{mg} / \mathrm{g})$ followed in PKV Rajat (7.226 mg/g); however, these two cultivars were at par with total sugar in DHY286, AKA-7 and AKA-8. LRA-5166, KDCH9632 and $\mathrm{KDCH}-9632 \mathrm{Bt}$. Varied amount of total soluble sugar was noted in genotype to genotype viz., hybrid, Tulasi 144 BG II (7.03$4.20 \mathrm{mg} / \mathrm{g}$ ), hybrid Jadoo BG II (5.27-2.38 $\mathrm{mg} / \mathrm{g}$ ), hybrid NCS 9605 (5.16-1.92 mg/g)and variety, NA $1325 \quad(4.77-1.59 \mathrm{mg} / \mathrm{g})$ by Venktesh et al., (2016).

\section{Total phenol in cotton leaves}

\section{First year}

Total phenol (Table 3 ) in cotton leaves 45 days after emergence ranged from $2.026 \mathrm{mg} / \mathrm{g}$ to $2.885 \mathrm{mg} / \mathrm{g}$. The highest total phenol (in DHY-286) was followed with 2.881, 2.823, 2.651, 2.545 and 2. $477 \mathrm{mg} / \mathrm{g}$ in PKVHY-2, PKV Rajat, LRA-5166, NHH-44 and NHH$44 \mathrm{Bt}$, respectively. The total phenol in KDCH-9632 (2.468 mg/g) and its counterpart Bt $(2.374 \mathrm{mg} / \mathrm{g})$ does not differ with each other and than phenol in LRA-5166, NH-44 and NH-44 Bt. The total phenol in rest of cultivars including BNBt (lowest) on par with total phenol in KDCH-9632 and KDCH-9632 Bt.

The total phenol estimated 60 days after emergence among the cultivars differ significantly and ranged from 2.291 and 3.167 $\mathrm{mg} / \mathrm{g}$. The highest total phenol was estimated in PKVHY-2 and does not differ significantly than the phenol in DHY-286, KDCH-9632, PKV Rajat, KDCH-9632 Bt, NHH-44 and LRA-5166. The lowest $(2.291 \mathrm{mg} / \mathrm{g})$ total phenol was in BNBt which was followed by 2.324 (RCH-2 and RCH-2 Bt.), 2.386 (AKA8), 2.405 (AKA-7), 2.622 (Bunny) 2.702 (Bunny), 2.718 (NHH-44 Bt) and 2.857 (LRA-5166) mg/g.

The mean of total phenol noted highest (3.024 $\mathrm{mg} / \mathrm{g}$ ) in PKVHY2 which was statistically similar in DHY-286 (2.987 mg/g), PKV Rajat $(2.863 \mathrm{mg} / \mathrm{g})$, LRA-5166 (2.754 mg/g) and NHH-44 (2.705 mg/g); however, latter three were at par to KDCH-9632, its counterpart Bt and $\mathrm{NHH}-44 \mathrm{Bt}$. Cultivar BN Bt was having lowest phenol i. e. $2.159 \mathrm{mg} / \mathrm{g}$ followed in RCH-2 Bt, RCH-2, AKA-7, AKA-8, Bunny and Bunny Bt.

\section{Second year}

Significantly highest total phenol 45 DAE was found in DHY-286, PKV Rajat and PKVHY-2 which were 2.890, 2.890 and $2.802 \mathrm{mg} / \mathrm{g}$, respectively; total phenol in these cultivars was significantly higher than rest of cultivars. The total phenol in remaining cultivars placed in descending order as 2.486, $2.450,2.414,2.407,2.397,2.374,2.355$, 2.326, 2.236, 2.192, 2.134 and 2.106 (least) $\mathrm{mg} / \mathrm{g}$ estimated in KDCH-9632, NHH-44, NHH-44 Bt, AKA-8, AKA-7, LRA-5166, Bunny Bt, KDCH-9632 Bt, Bunny, RCH-2, $\mathrm{BNBt}$ and $\mathrm{RCH}-2 \mathrm{Bt}$, respectively.

The highest total phenol 60 DAE was estimated in cultivar PKVHY-2 $(3.149 \mathrm{mg} / \mathrm{g})$ followed in DHY-286 (3.105 mg/g), KDCH9632 (2.952 mg/g), PKV Rajat (2.931 mg/g), KDCH-9632 Bt (2.899 mg/g), LRA-5166 (2.891 mg/g), NHH-44 (2.856 mg/g) and $\mathrm{NHH}-44 \mathrm{Bt}(2.732 \mathrm{mg} / \mathrm{g})$. The phenol in latter (NHH-44 Bt) was at par to the total phenol in rest of the cultivars which were placed in 
ascending order as $\mathrm{RCH}-2 \mathrm{Bt}$ (least phenol), BNBt, RCH-2, AKA-8, AKA-7, Bunny and Bunny Bt.

The mean total phenol differ significantly and ranged from 2.212 in $\mathrm{RCH}-2 \mathrm{Bt}$ to 2.997 $\mathrm{mg} / \mathrm{g}$ in DHY-286. The maximum total phenol (DHY-286) was followed in PKVHY2, PKV Rajat and KDCH-9632 with 2.975, 2.911 and $2.719 \mathrm{mg} / \mathrm{g}$, respectively. The least total phenol was estimated in $\mathrm{RCH}-2 \mathrm{Bt}$ $(2.212 \mathrm{mg} / \mathrm{g})$.

Table.1 Crude protein (\%) in cotton leaves (first year, second year and pooled mean)

\begin{tabular}{|c|l|c|c|c|c|c|c|c|c|c|}
\hline $\begin{array}{c}\text { Tr. } \\
\text { No. }\end{array}$ & Cotton cultivars & \multicolumn{3}{|c|}{ First Year } & \multicolumn{3}{c|}{ Second Year } & \multicolumn{3}{c|}{ Pooled } \\
\hline & & $\begin{array}{c}\text { 45 } \\
\text { DAE }\end{array}$ & DAE & Mean & $\begin{array}{c}\text { D5 } \\
\text { DAE }\end{array}$ & DAE & Mean & 45 & 60 & MAE \\
DAE & \\
\hline T-1 & PKV HY-2 & 18.62 & 18.43 & 18.53 & 19.11 & 19.06 & 19.08 & 18.87 & 18.75 & 18.80 \\
\hline T-2 & NHH-44 & 20.45 & 20.31 & 20.36 & 21.08 & 20.98 & 21.03 & 20.74 & 20.65 & 20.69 \\
\hline T-3 & NHH-44 Bt & 20.98 & 20.89 & 20.93 & 21.32 & 21.22 & 21.27 & 21.15 & 21.06 & 21.10 \\
\hline T-4 & BN Bt & 22.47 & 22.38 & 22.43 & 22.72 & 22.62 & 22.67 & 22.60 & 22.50 & 22.55 \\
\hline T-5 & RCH-2 & 22.09 & 21.99 & 22.04 & 22.43 & 22.33 & 22.38 & 22.26 & 22.16 & 22.21 \\
\hline T-6 & RCH-2 Bt & 22.52 & 22.43 & 22.47 & 23.00 & 22.91 & 22.96 & 22.76 & 22.67 & 22.72 \\
\hline T-7 & Bunny & 21.46 & 20.31 & 20.89 & 21.75 & 21.66 & 21.70 & 21.61 & 20.98 & 21.30 \\
\hline T-8 & Bunny Bt & 21.90 & 21.70 & 21.80 & 22.14 & 22.04 & 22.09 & 22.02 & 21.87 & 21.95 \\
\hline T-9 & KDCH-9632 & 21.42 & 21.22 & 21.32 & 21.56 & 21.46 & 21.51 & 21.49 & 21.34 & 21.42 \\
\hline T-10 & KDCH-9632 Bt & 21.85 & 21.66 & 21.75 & 22.04 & 21.95 & 21.99 & 21.95 & 21.80 & 21.87 \\
\hline T-11 & LRA-5166 & 21.99 & 21.80 & 21.90 & 22.52 & 22.43 & 22.47 & 22.26 & 22.11 & 22.19 \\
\hline T-12 & DHY-286 & 18.48 & 18.29 & 18.38 & 18.58 & 18.53 & 18.55 & 18.53 & 18.41 & 18.47 \\
\hline T-13 & PKV Rajat & 19.20 & 19.11 & 19.15 & 19.15 & 19.11 & 19.13 & 19.18 & 19.11 & 19.14 \\
\hline T-14 & AKA-8 & 19.06 & 18.96 & 19.01 & 19.73 & 19.64 & 19.68 & 19.39 & 19.30 & 19.35 \\
\hline T-15 & AKA-7 & 18.87 & 18.62 & 18.74 & 19.97 & 19.97 & 19.97 & 19.42 & 19.30 & 19.36 \\
\hline & SE(m) \pm & 0.653 & 0.649 & 0.573 & 0.699 & 0.690 & 0.522 & 0.613 & 0.517 & 0.468 \\
\hline & CD at 5\% & 1.980 & 1.968 & 1.739 & 2.121 & 2.094 & 1.585 & 1.858 & 1.568 & 1.419 \\
\hline & CV (\%) & 5.45 & 5.47 & 4.81 & 5.73 & 5.68 & 4.29 & 5.07 & 4.30 & 3.88 \\
\hline
\end{tabular}


Table.2 Total sugar $(\mathrm{mg} / \mathrm{g})$ in cotton leaves (first year, second year and pooled mean)

\begin{tabular}{|c|c|c|c|c|c|c|c|c|c|c|}
\hline \multirow{2}{*}{$\begin{array}{l}\text { Tr. } \\
\text { No. }\end{array}$} & \multirow{2}{*}{$\begin{array}{l}\text { Cotton } \\
\text { cultivars }\end{array}$} & \multicolumn{3}{|c|}{ First Year } & \multicolumn{3}{|c|}{ Second Year } & \multicolumn{3}{|c|}{ Pooled Mean } \\
\hline & & $\begin{array}{c}45 \\
\text { DAE }\end{array}$ & $\begin{array}{c}60 \\
\text { DAE }\end{array}$ & Mean & $\begin{array}{c}45 \\
\text { DAE }\end{array}$ & $\begin{array}{c}60 \\
\text { DAE }\end{array}$ & Mean & $\begin{array}{c}45 \\
\text { DAE }\end{array}$ & $\begin{array}{c}60 \\
\text { DAE }\end{array}$ & Mean \\
\hline $\mathbf{T}-\mathbf{1}$ & PKV HY-2 & 7.350 & 6.906 & 7.128 & 7.379 & 6.980 & 7.180 & 7.365 & 6.943 & 7.154 \\
\hline T-2 & $\mathrm{NHH}-44$ & 8.477 & 8.061 & 8.269 & 8.414 & 8.105 & 8.259 & 8.445 & 8.083 & 8.264 \\
\hline $\mathbf{T}-\mathbf{3}$ & NHH-44 Bt & 8.550 & 8.112 & 8.331 & 8.407 & 8.175 & 8.291 & 8.479 & 8.144 & 8.311 \\
\hline T-4 & $\mathrm{BN} B t$ & 8.983 & 8.778 & 8.881 & 9.014 & 8.863 & 8.939 & 8.999 & 8.821 & 8.910 \\
\hline T-5 & $\mathrm{RCH}-2$ & 8.987 & 8.745 & 8.866 & 8.944 & 8.865 & 8.905 & 8.965 & 8.805 & 8.885 \\
\hline T-6 & $\mathrm{RCH}-2 \mathrm{Bt}$ & 9.063 & 8.901 & 8.982 & 9.117 & 9.110 & 9.114 & 9.090 & 9.005 & 9.048 \\
\hline T-7 & Bunny & 8.680 & 8.435 & 8.557 & 8.698 & 8.397 & 8.547 & 8.689 & 8.416 & 8.552 \\
\hline T-8 & Bunny Bt & 8.847 & 8.536 & 8.691 & 8.887 & 8.617 & 8.752 & 8.867 & 8.576 & 8.722 \\
\hline T-9 & KDCH-9632 & 8.187 & 7.889 & 8.038 & 8.221 & 8.048 & 8.134 & 8.204 & 7.968 & 8.086 \\
\hline T-10 & KDCH-9632 Bt & 8.323 & 7.901 & 8.112 & 8.207 & 8.040 & 8.123 & 8.265 & 7.971 & 8.118 \\
\hline T-11 & LRA-5166 & 7.923 & 7.547 & 7.735 & 7.962 & 7.608 & 7.785 & 7.943 & 7.578 & 7.760 \\
\hline T-12 & DHY-286 & 7.402 & 7.023 & 7.213 & 7.445 & 7.092 & 7.269 & 7.424 & 7.057 & 7.241 \\
\hline T-13 & PKV Rajat & 7.445 & 6.947 & 7.196 & 7.573 & 6.937 & 7.255 & 7.509 & 6.942 & 7.226 \\
\hline T-14 & AKA-8 & 7.560 & 7.067 & 7.313 & 7.605 & 7.148 & 7.377 & 7.583 & 7.108 & 7.345 \\
\hline \multirow[t]{4}{*}{ T-15 } & AKA-7 & 7.422 & 7.063 & 7.242 & 7.507 & 7.014 & 7.261 & 7.465 & 7.038 & 7.251 \\
\hline & $\mathrm{SE}(\mathrm{m}) \pm$ & 0.293 & 0.325 & 0.251 & 0.288 & 0.308 & 0.238 & 0.188 & 0.213 & 0.155 \\
\hline & $\mathrm{CD}$ at $5 \%$ & 0.887 & 0.985 & 0.761 & 0.875 & 0.934 & 0.723 & 0.570 & 0.647 & 0.469 \\
\hline & $\mathrm{CV}(\%)$ & 6.17 & 7.16 & 5.41 & 6.07 & 6.72 & 5.11 & 3.96 & 4.68 & 3.32 \\
\hline
\end{tabular}


Table.3Total phenol $(\mathrm{mg} / \mathrm{g})$ in leaves of different cotton cultivars (first year, second year and pooled mean)

\begin{tabular}{|c|c|c|c|c|c|c|c|c|c|c|}
\hline \multirow{2}{*}{$\begin{array}{l}\text { Tr. } \\
\text { No. }\end{array}$} & \multirow[t]{2}{*}{ Cotton cultivars } & \multicolumn{3}{|c|}{ First Year } & \multicolumn{3}{|c|}{ Second Year } & \multicolumn{3}{|c|}{ Pooled Mean } \\
\hline & & $\begin{array}{c}45 \\
\text { DAE }\end{array}$ & $\begin{array}{c}60 \\
\text { DAE }\end{array}$ & Mean & $\begin{array}{c}45 \\
\text { DAE }\end{array}$ & $\begin{array}{c}60 \\
\text { DAE }\end{array}$ & Mean & $\begin{array}{c}45 \\
\text { DAE }\end{array}$ & $\begin{array}{c}60 \\
\text { DAE }\end{array}$ & Mean \\
\hline T-1 & PKV HY-2 & 2.881 & 3.167 & 3.024 & 2.802 & 3.149 & 2.975 & 2.841 & 3.158 & 2.999 \\
\hline T-2 & NHH-44 & 2.545 & 2.865 & 2.705 & 2.450 & 2.856 & 2.653 & 2.497 & 2.860 & 2.679 \\
\hline T-3 & NHH-44 Bt & 2.477 & 2.718 & 2.598 & 2.414 & 2.723 & 2.569 & 2.446 & 2.721 & 2.583 \\
\hline T-4 & Bikaneri Nerma Bt & 2.026 & 2.291 & 2.159 & 2.134 & 2.323 & 2.229 & 2.080 & 2.307 & 2.194 \\
\hline T-5 & $\mathrm{RCH}-2$ & 2.161 & 2.324 & 2.243 & 2.192 & 2.361 & 2.276 & 2.177 & 2.343 & 2.260 \\
\hline T-6 & $\mathrm{RCH}-2 \mathrm{Bt}$ & 2.078 & 2.324 & 2.201 & 2.106 & 2.317 & 2.212 & 2.092 & 2.321 & 2.206 \\
\hline T-7 & Bunny & 2.281 & 2.622 & 2.451 & 2.236 & 2.654 & 2.445 & 2.258 & 2.638 & 2.448 \\
\hline T-8 & Bunny Bt & 2.211 & 2.702 & 2.456 & 2.355 & 2.667 & 2.511 & 2.283 & 2.684 & 2.484 \\
\hline T-9 & KDCH-9632 & 2.468 & 2.928 & 2.698 & 2.486 & 2.952 & 2.719 & 2.477 & 2.940 & 2.709 \\
\hline T-10 & KDCH-9632 Bt & 2.374 & 2.897 & 2.636 & 2.326 & 2.899 & 2.612 & 2.350 & 2.898 & 2.624 \\
\hline T-11 & LRA-5166 & 2.651 & 2.857 & 2.754 & 2.374 & 2.891 & 2.632 & 2.513 & 2.874 & 2.693 \\
\hline T-12 & DHY-286 & 2.885 & 3.090 & 2.987 & 2.890 & 3.105 & 2.997 & 2.887 & 3.098 & 2.992 \\
\hline T-13 & PKV Rajat & 2.823 & 2.904 & 2.863 & 2.890 & 2.931 & 2.911 & 2.857 & 2.917 & 2.887 \\
\hline T-14 & AKA-8 & 2.357 & 2.386 & 2.371 & 2.407 & 2.434 & 2.421 & 2.382 & 2.410 & 2.396 \\
\hline \multirow[t]{4}{*}{ T-15 } & AKA-7 & 2.263 & 2.405 & 2.334 & 2.397 & 2.452 & 2.424 & 2.330 & 2.429 & 2.379 \\
\hline & $\mathrm{SE}(\mathrm{m}) \pm$ & 0.142 & 0.151 & 0.108 & 0.102 & 0.156 & 0.100 & 0.067 & 0.112 & 0.072 \\
\hline & $\mathrm{CD}$ at $5 \%$ & 0.430 & 0.458 & 0.327 & 0.309 & 0.474 & 0.303 & 0.205 & 0.339 & 0.219 \\
\hline & $\mathrm{CV}(\%)$ & 10.09 & 9.69 & 7.29 & 7.26 & 9.98 & 6.73 & 4.81 & 7.16 & 4.86 \\
\hline
\end{tabular}


Table.4 Correlation of major sucking pests and biochemical constituents in cotton leaves

\begin{tabular}{|l|c|c|c|c|}
\hline \multicolumn{1}{|c|}{ Biochemical } & Aphids & Leafhoppers & Thrips & Whitefly \\
\hline Protein & 0.090 & $0.717^{* *}$ & 0.174 & 0.009 \\
\hline Total Sugar & 0.203 & $0.855^{* *}$ & 0.102 & 0.002 \\
\hline Total Phenol & -0.044 & $-0.486^{* *}$ & 0.202 & $0.472^{* *}$ \\
\hline $\mathbf{N = 3 0}$ & $\mathrm{r}=0.361(5 \%)$ & $\mathrm{r}=0.463(1 \%)$ & & \\
\hline
\end{tabular}

\section{Pooled}

The pooled mean data of total phenol $45 \mathrm{DAE}$ among the cultivars differ significantly and ranged from 2.080 and $2.887 \mathrm{mg} / \mathrm{g}$. The highest total phenol was estimated in DHY286 and this was not differred significantly than the phenol in PHVHY-2 $(2.841 \mathrm{mg} / \mathrm{g})$ and PKV Rajat $(2.857 \mathrm{mg} / \mathrm{g})$. The lowest $(2.080 \mathrm{mg} / \mathrm{g})$ total phenol was estimated in BNBt which was followed by 2.092 (RCH-2 Bt.), 2.177 (RCH-2), 2.258 (Bunny), 2.283 (Bunny Bt) and 2.330 (AKA-7) $\mathrm{mg} / \mathrm{g}$. The cultivars LRA-5166, NHH-44, KDCH-9632, NHH-44 Bt, AKA-8, Bunny and KDCH-9632 Bt were noted 2.513, 2.497, 2.477, 2.446, 2.382 and $2.350 \mathrm{mg} / \mathrm{g}$.

The total phenol 60 days after emergence was highest of $3.158 \mathrm{mg} / \mathrm{g}$ in PKVHY2 which was statistically similar in DHY-286 $(3.098 \mathrm{mg} / \mathrm{g})$, Bunny $(2.940 \mathrm{mg} / \mathrm{g})$, PKV Rajat $(2.917 \mathrm{mg} / \mathrm{g})$, KDCH-9632 Bt, LRA-5166 (2.874mg/g) and NHH-44 $(2.860 \mathrm{mg} / \mathrm{g})$. The cultivars NHH-44 Bt, Bunny Bt and Bunny showed 2.721, 2.684 and $2.638 \mathrm{mg} / \mathrm{g}$ total phenol, respectively. The mean total phenol in Bt cultivars viz., NHH-44 Bt, Bunny Bt, KDCH-9632 Bt and $\mathrm{RCH}-2 \mathrm{Bt}$ was more than in their non $\mathrm{Bt}$ versions.

Mean total phenol in cotton leaves was on higher side in cultivar PKVHY-2 which being hand in hand with 2.992 and $2.887 \mathrm{mg} / \mathrm{g}$ in leaves of DHY-286 and PKV Rajat; latter was statistically equal with phenol in KDCH-9632
(2.709 mg/g), LRA-5166 (2.693 mg/g) and NHH-44 (2.679 mg/g). BNBt resulted least i.e. $2.194 \mathrm{mg} / \mathrm{g}$ total phenol and was being at par with total phenol in $\mathrm{RCH}-2 \mathrm{Bt}, \mathrm{RCH}-2$, AKA-7 and AKA-8.

The varied amount of total phenols in leaves of cotton genotypes were reported earlier by Venktesh et al., (2016); the authors noted the total phenols in the range 2.10 to $1.33 \mathrm{mg} / \mathrm{g}$, in hybrid Tulasi 144 BG II, 1.95 to $1.19 \mathrm{mg} / \mathrm{g}$ in hybrid Jadoo BG II, 1.76 to $0.95 \mathrm{mg} / \mathrm{g}$ in hybrid NCS 9605 and 1.58 to $0.50 \mathrm{mg} / \mathrm{g}$ in variety NA 1325. Divya et al., (2017) observed the higher phenol content of resistant cotton CPD14-1 at 45 (7.35, g/100g dry weight) than in susceptible cotton CPD14-2 genotype (6.88, g/100g dry weight); the resistant genotype exhibited higher total phenol content compared to susceptible. High phenol $(1029.75 \mathrm{mg} / \mathrm{g})$ was observed in genotype C-1622 (Small leaf and medium ball size) and low (310.95 mg/g) in genotype Demeter 111(1) (Big ball size) by Ramani et al., (2017).

\section{Correlation of major sucking pests and biochemical constituents}

The correlation coefficients of major sucking pests and biochemical constituents were on the basis of mean of 45 and 60 DAE data of two years. The aphids had non significant correlation with all biochemical viz., crude protein, total sugar and total phenol in cotton leaves. 
The leafhopper population had significant positive correlation with crude protein $(\mathrm{r}=0.717)$ and total sugar $(\mathrm{r}=0.855)$; whereas, significant negative correlation with total phenol $(\mathrm{r}=-0.486)$ in cotton leaves. The development and survival of cotton leafhopper was studied on 12 host plant species including cotton in relation to biochemical, total phenol at Hissar by Sharma and Singh (2001) and reported non-significant relationship with biological parameters of leafhopper. These findings partially confirmed by present findings. Vanitha et al., (2007) made efforts to identify the leafhopper resistant cotton genotypes and observed no significant influence of phenol on the growth and development of leafhopper, Amrasca bigutula bigutula.

Any of the constituent viz., crude protein, total sugar and total phenol had no significant impact on thrips.

The whitefly adult population was affected positively and significantly by increased total phenol $(r=0.472)$ in cotton leaves, while the other constituents viz., crude protein and total sugar does not had any significant impact on whitefly population fluctuation. Under glasshouse condition eight cotton cultivars (G. hirsutum) were studied by Raghuraman et al., (2004) for relationship of biochemical constituents of leaves with population of whitefly B. tabaci (Genn.) at the IARI, New Delhi, India. The findings of present study partially confirms the outcome of Raghuraman and associates who reported no any significant correlation of total sugar and significant negative correlation with the population of B. tabaci (Genn.). In the present study also, no any significant impact of total sugar was noted on whitefly population. The relationship with biochemical constituents of leaves and whitefly, B. tabaci Genn., on 25 genotypes of cotton was studied at ARS, Srigangangar (Acharya and Singh, 2008). The total phenol was found non-significant negative relationship with the population density of whitefly. Similarly, Reddy and Rao (1989) and Kumar et al., (1999) reported non significant negative correlation with phenol in cotton leaves and whitefly population.

It is concluded that there was weak nonsignificant correlation between aphid nymphs and biochemical viz., crude protein, total sugar and total phenol in leaves. However, there was positive significant correlation between leafhoppers and crude protein, total sugar and negative significant correlation between leafhopper and total phenol in leaves. The whitefly adults had significant positive correlation with total phenol; whereas, other biochemical were not played much role in imparting resistance or susceptibility.

\section{References}

Acharya, V. S. and A. P. Singh. 2008. Biochemical basis of resistance in cotton to the whitefly, Bemicia tabaci Genn. J.Cotton Res. Dev. 22(2):195-199.

Ahmad, M., M. I. Arif, Z. Ahmad and I. Denholm. 2002. Cotton whitfly (Bemicia tabaci) resistance to organophosphate and pyrethroid insecticides in Pakistan. Pest Manag. Sci. 58:203-208.

Bray, H.G and W.V. Thorpe. 1954. Estimation of total phenol from plant tissues. Meth. Biochem. Annal.1:27-52.

Chaman, M. E, L. J. Corcuera, G.E. Zuniga, L. Cardemill and V. H. Argandona. 2001. Induction of soluble and cell wall peroxides by aphid infestation in barley. J. Agric. Food Chem. 49:2249-2253.

Divya, T.C., Katageri, I.S., Jadhav, M.P., Adiger, S., Vamadevaiah, H.M., Nagaratna S. Olekar. 2017. Biochemical Constituents Imparting Resistance to Sucking Pest Aphid in Cotton (Gossypium spp.), Int.J.Curr.Microbiol.App.Sci 6(12): 
2749-2757.

Dubois, M., K. A. Gilles, J. K. Hamilton, P.A. Roberts and F. Smith. 1956. Colorimetric methods for determination of sugar and related substances. Annal. Chem 28:350356.

Gomez, K. A. and A.A.Gomez. 1984. Statistics for Agriculture Researc, $2^{\text {nd }}$ Edn. John Wiley and Sons, New York.

Hopkins, W.G and N. P. A. Huner. 2004. Introduction to plant physiology, John Wiley and Sons Inc. USA:479-481.

Kumar, S. P., P. Jaykumar and G. P. Gupta. 1999. Leaf hair density and total phenol imparting resistance to Bemisia tabaci (Genn.) in cotton. J. Cotton Res. Dev. 13:170-172.

Nelson, M. R., A. Nadeem, W. Ahmad and T. V. Orum. 1998. Global assessment of cotton viral diseases. pp. 161-162.In Proc. Beltwide Cotton Conf., San Diego, CA 5-9 Jan 1998,Natl.Cotton Counc. Am., Memphis, T.N.

Ni, X., S. S. Quisenberry, J. Heng-Moss., J. Markwell, G. Sarath, R. Klucas and F. Baxendale 2001. Oxidative Responses of resistant and susceptible cereal leaves to symptomatic and non-symptomatic cereal aphid (Hemiptera: Aphididae) feeding. J. Econ. Entomol. 94:743-751.

Pawar U. M. and J. R. Kadam. 1995. Entomological aspects of IPM in important crop Maharashtra State. State level conference on IPM: 20-40.

Piper, C.S. 1966. Soi and Plant Analysis. Hans Publishers, Bombay.

Rafie, M. M., R. S. Zemetra and S.S. Quisenberry. 1996. Interaction between Russian wheat aphid (Hemiptera:
Aphididae) and resistant and susceptible genotypes of wheat. J. Econ. Entomol 89:239-246.

Raghuraman, M., G. P. Gupta and R. P. Singh 2004. Biochemical constituents imparting resistance in upland cotton (Gossypium hirsutum) to whitefly (Bemisia tabaci). Indian Journal of Agricultural Sciences 74(9):505-507. ISSN 0019-5022 Record Number 20053035404

Ramani, H.R., Shobha Sing2, Patel, D.H., Solanki, B.G. 2017. Biochemical constitutes of different cotton (Gossypium hirsutum) germplasm, International Journal of Science, Environment and Technology, 6 (2): 1055-1060.

Reddy A. S. and N. V. Rao. 1989. Cotton whitefly (Bemisia tabaci Genn.)- a review. Indian J. Pl. Prot. 17:171-179.

Sharma, A. and R. Singh. 2001. Survival and development of cotton leafhopper, Amrasca bigutula bigutula (Ishida) in relation to some biochemical and morphological characteristics on plants. J. Cotton Res. Dev. 15(2):191-195.

Vanitha, R., P. Sivasubramanian, N. Sivasamy and P. Amla Balu. 2007.Biophysical and biochemical aspects of resistance in wild species of cotton towards leafhopper, Amrasca bigutula bigutula (Ishida).Cotton Res. Dev. 21(2):235-238.

Venkatesh, I., BhattiprolU, S. L., Krishna Prasadji, J. and Ramachandra Rao, G. 2016. Biochemical analysis of cotton genotypes infected with Alternaria leaf spot disease, J. Cotton Res. Dev. 30 (2) :265-270

\section{How to cite this article:}

Sonalkar, V. U. 2020. Biochemicals in Cotton Hybrids and Varieties and their Correlation with Sucking Insect Pests. Int.J.Curr.Microbiol.App.Sci. 9(01): 1172-1183. doi: https://doi.org/10.20546/ijcmas.2020.901.132 